\title{
A SYNOPSIS OF THE GENUS PLANTAGO L. IN TASMANIA
}

\author{
by M.J. Brown
}

(with one table)

\begin{abstract}
An account of the genus Plantago in Tasmania is presented. The taxonomic, biogeographic and cytological relationships of the genus are reviewed. Current knowledge on ecological and cytological data for the Tasmanian taxa is included and a key to the Tasmanian species is presented.
\end{abstract}

Key Words: Plantago, cytology, breeding systems, taxonomy, Tasmania.

In BANKS, M.R. et al. (Eds), 1991 (31:iii): ASPECTS OF TASMANIAN BOTANY - A TRIBUTE TO WINIFRED

CURTIS. Roy. Soc. Tasm. Hobart: 65-74. https://doi.org/10.26749/rstpp.124.2.65

\section{INTRODUCTION}

The family Plantaginaceae is composed of rosulate annual or perennial herbs and contains three genera: Bougueria, Littorella and Plantago. The flowers are usually in heads or spikes, bracteate, hermaphrodite, regular and predominantly anemophilous. The floral structure is described in detail in Curtis (1967), Willis (1973) and Briggs et al. (1977), and is characterised by: sepals four, $( \pm)$ free, imbricate, diagonal, equal or unequal, persisting in the fruiting stage; a gamopetalous corolla with 3 or 4 imbricate and membranous lobes. The ovary is superior, 2-capellary (sometimes 1capellary), (1 )2-locular, sometimes up to 4-locular by the development of false septa. The fruit is a membranous capsule with circumscissile dehiscence (Plantago) or an indehiscent, one-seeded nut (Littorella, Bougueria).

The family occurs throughout the temperate and cold temperate regions of the world, including mountains of the tropics. The genus Littorella has one species in each of North America, South America and Europe. Bougueria is a monotypic genus restricted to the Andes. The genus Plantago contains about 260 species, of which 200 can be considered as local or regional endemics (i.e. occupying a limited range), and only 29 have a wide or discontinuous range (Good 1965). The genus therefore exhibits a fairly high degree of speciation apparently arising from geographical isolation.

\section{CLASSIFICATION OF THE PLANTAGINACEAE}

The affinities of the Plantaginaceae are not clear and, on the basis of the morphological characters, the family has been placed variously in the Scrophulariales near the Scrophulariaceae (Lawrence 1951, De Wit 1965, Takhtajan 1969, Willis 1973, Dahlgren 1975), in the
Primulales (Bessey 1897) and in the Bignoniales (Thorne 1968). On the other hand, a number of authors consider that it belongs in the separate order Plantaginales (Bentham \& Hooker 1862-83, Engler 1954 [quoted in Willis 1973], Benson 1957, Hutchinson 1959, 1969, Cronquist 1968).

The first systematic classification of the family was published by Barneoud (1845), who recognised three genera and subdivided the genus Plantago into six sections. Decaisne (1852) subsequently divided this genus into 17 sections. Engler \& Prantl (1897) recognised 12 sections within Plantago; these were divided among two subgenera, one of which contained a single section. Pilger's (1937) classification recognised two subgenera within Plantago: Euplantago, with 247 species divided among 18 sections, and Psyllium, containing 13 species in a single section.

In Australia, only two of Pilger's sections (Oliganthos, Mesembrynia) are represented by native species. Briggs et al. $(1973,1977)$ reviewed the taxonomy of some of these species using cytological and morphological criteria. They stated that considerable revision of Pilger's classification is necessary and, in particular, they queried the division of the Australian species into two sections. Examples of species which combine "diagnostic" characteristics of both sections are not infrequent, and they cite as typical $P$. cladarophylla, a species which exhibits considerable similarity to some members of section Oliganthos whilst having fruit characters typical of Mesembrynia.

Species of the section Oliganthos are characterised by a bilocular ovary which has four to many ovules per loculus. Members of section Mesembrynia have a trilocular ovary which is formed by the development of a false septum. Some discrepancies from this classification have been found in the Tasmanian species, both by Curtis (1967) and during the present study. For example, $P$. debilis, $P$. varia, $P$. bellidioides and $P$. antarctica are assigned to section Mesembrynia 
by Pilger, but Curtis (1967) stated that $P$. debilis has a bilocular ovary, and that the presence of a trilocular ovary is not constant in the other three species. These observations have been confirmed in the present study but, for convenience, the classification of Pilger has been retained for the present.

\section{PLANTAGO IN TASMANIA}

Eighteen species and a number of varieties and subspecies have been recorded for Tasmania at various times, but I have not been able to confirm the presence of P. muelleri. Four species are introduced: $P$. lanceolata, $P$. major and $P$. coronopus are of Eurasian origin whilst $P$. australis is from South America. Six of the native species are endemic to Tasmania ( $P$. glabrata, $P$. daltonii, $P$. paradoxa, $P$. bellidioides, $P$. gunnii and $P$. tasmanica). Four of the species also occur on the Australian mainland ( $P$. varia, $P$. hisipida, $P$. debilis, $P$. antarctica). Plantago triantha has a disjunct distribution, being found in Tasmania and on some of the offshore islands of New Zealand.

Some Tasmanian specimens of $P$. glabrata bear a strong superficial resemblance to the mainland species $P$. alpestris and $P$. euryphylla, but they differ in important respects. More detailed study is required to determine the status of these morphs.

The Tasmanian species fall fairly naturally into altitudinal groupings, and to some extent reflect differences in effective rainfall. Thus the coastal species $P$. triantha is restricted to the west and southeast coasts, and is replaced in similar habitats on the north and east coasts by $P$. hispida. With the possible exception of the introduced $P$. major, which preferentially grows in fertiliser-enriched pastures and lawns, and the cushion plant-epiphyte $P$. gunnii, the species do not appear to be specifically associated either with soil type or geological substrate. For example, $P$. tasmanica is restricted to the upland areas of Tasmania, and grows on sedimentary rocks of Permian age on Mt Maurice in northeastern Tasmania, on the Jurassic dolerite of the Central Plateau and southern mountains, and on Precambrian metaquartzites on Frenchmans Cap in the west.

The nomenclature used here for the Tasmanian species is essentially that of Curtis (1967). However, the review of New South Wales representatives by Briggs et al. (1973, 1977), and field and herbarium investigations during the present study have resulted in changes to the treatment by Curtis (see below).

A key to the genus in Tasmania is presented opposite.

\section{SYNOPSIS OF SPECIES}

The species are listed below according to Pilger's (1937) classification, with the exception of $P$. australis which has been placed in section Virginica by Rahn (1974).

\section{Section Polyneuron}

\section{Plantago major L.}

Description: Curtis (1967), Briggs et al. (1977).

Habitat: A widespread weed which is confined largely to fertiliser-enriched lawns and pastures in lowland areas.

Chromosome number: $2 \mathrm{n}=12$.

Distribution: Introduced, native in Europe and Asia.

Section Oliganthos

\section{Plantago tasmanica Hook.f. ssp. tasmanica W.M. Curtis}

Description: Curtis (1967), but see Brown (1981).

Habitat: Occurs in a wide range of habitats (Astelia alpina wet bogs, open shrublands, bare areas) in alpine Tasmania.

Chromosome number: $2 \mathrm{n}=12$.

Distribution: Tasmania (Victoria).

Comments: Although not listed as such by Curtis (1967), this species appears to be endemic to Tasmania. Reports of its occurrence in Victoria (e.g. Curtis 1967, Willis 1972) probably have resulted from confusion with $P$. alpestris (B. Briggs, pers. comm.). Its taxonomic status has been clarified by Brown (1981), using morphometric, seed germination and ecological characteristics. In that paper, the specific rank of $P$. daltonii was retained but varietal rank for $P$. tasmanica var. tasmanica and $P$. tasmanica var. archeri was recommended. 


\section{A KEY TO THE TASMANIAN SPECIES OF PLANTAGO}

Flowers cleistogamous (corolla lobes erect, appressed, persistent, anthers not exserted ........P. australis

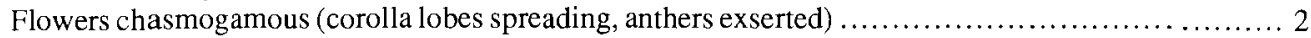
Scapes furrowed, anterior sepals fused for at least $1 / 2$ their length $\ldots \ldots \ldots \ldots \ldots \ldots \ldots \ldots \ldots$. lanceolata

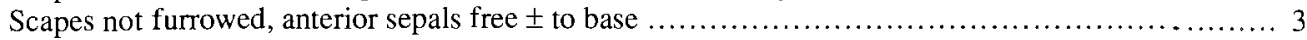




Scapes slender, 0.5-1.8 mm diam., mostly longer than leaves; bracts mostly longer than sepals; keel of anterior sepals \pm equal to membranous margins ........................ coronopus ssp. coronopus Scapes stout, 1.3-2.3 mm diam., shorter than or equal to leaves; bracts mostly shorter than or equal to sepals; keel of anterior sepals much broader than membranous margins...... P. coronopus ssp. commutata Leaves broadly ovate, with 5-7 \pm equal veins and narrowed abruptly to a long winged petiole; capsules with

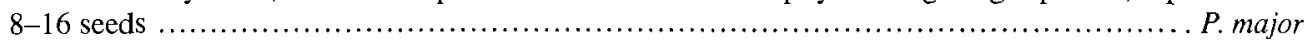

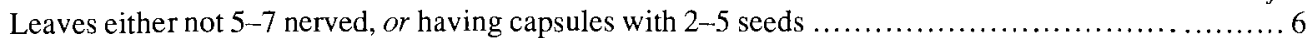

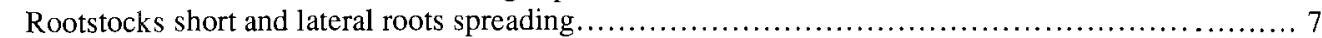

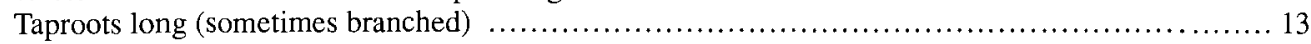
Plants with thick leaves which are densely tomentose, shortly petiolate; spikes cylindrical; seeds

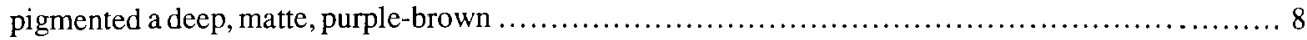
Plants with leaves glabrous or sparingly hispid, or if tomentose, then spikes capitate and seeds pale brown,

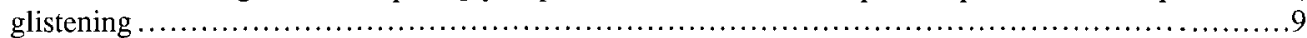
Fruiting scapes approximately twice leaf length ........................ tasmanica var. tasmanica Fruiting scapes scarcely as long as the leaves ............................ tasmanica var. archeri Leaves spathulate with an indumentum of long pilose hairs spread evenly over the upper surface. Small plants growing in alpine cushion plants............................................. gunnii

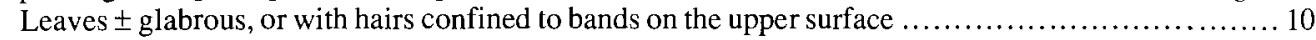

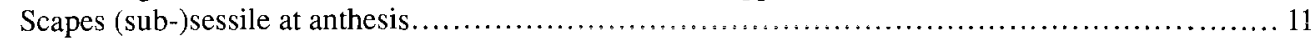

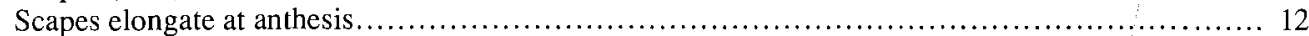
Plants with an axillary tuft of golden brown hairs; leaves glabrous; seeds (1-) 4 ...........P. muelleri Plants with an axillary tuft of silvery-white hairs (if present); leaves with bands of hairs \pm across the blade;

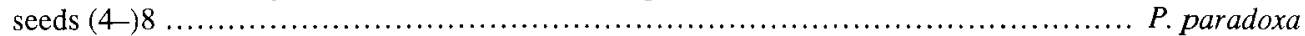
Flowers crowded in a cylindrical (but sometimes reduced) spike; petioles about as long as the blade; axillary hairs silvery-white and with a tuft of hairs in the axil of the bract $\ldots \ldots \ldots \ldots \ldots \ldots \ldots \ldots . .$. daltonii Flowers (1-)2-3(-5) on a capitate spike; petioles shorter than the blade; axillary hairs golden brown; tuft of hairs absent from the axil of the bract............................................... glacialis Leaves \pm glabrous, fleshy, $3-5$ cuspid, bracts and sepals glabrous; plants of coastal rocks......P. triantha

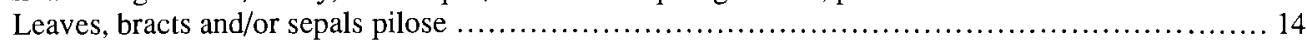

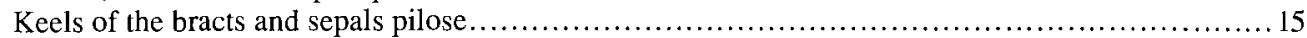
Keels of sepals \pm glabrous; bracts glabrous or with fimbriate-iliate margins .................... 18 Bracts minute, or if long, then less than half the calyx length; hairs in leaf axils short, whitish or pale yellowbrown P. hispida Bracts greater than half sepal length; hairs in leaf axils long, tufted, deep golden brown ...............16 Leaves broadly obovate, anterior sepals, $1.8-2 \mathrm{~mm}$ long, narrowly elliptic; bracts $\pm 2 / 3$ sepals

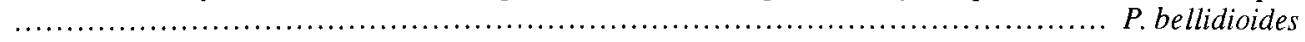
Leaves linear to lanceolate; anterior sepals 2.8-3.5 mm long, broadly elliptic-obovate; bracts \pm equal sepals Leaves linear to narrow elliptic \pm glabrous, length more than 15 times than breadth Bracts fimbriate-ciliate, as long or longer than the calyces P. gaudichaudii Bracts entire, shorter than the calyx. P. glabrata Scapes slender bearing interrupted spikes of small, distant flowers P. debilis Spikes dense; flowers closely imbricate 


\section{Plantago tasmanica Hook.f. ssp. archeri (Hook.f.) W.M. Curtis}

Description: Curtis (1967) but see Brown (1981).

Habitat: Occurrence as $P$. tasmanica var. tasmanica.

Chromosome number: $2 \mathrm{n}=$ ?

Distribution: Endemic.

\section{Plantago daltonii Decne}

Description: Curtis (1967), but see Brown (1981).

Habitat: Edges of streams, lakes and sites of frequent flooding in sub-alpine and alpine Tasmania. Also on river banks to sea level on the west coast.

Chromosome number: $2 \mathrm{n}=12$.

Distribution: Endemic.

\section{Plantago paradoxa Hook.f.}

Description: Curtis (1967), but see Brown (1983).

Habitat: Grasslands, herbfields in depressions and margins of lakes and streams of sub-alpine and alpine areas, river banks to sea level on the west coast. Also found in bolster moor communities.

Chromosome number: $2 n=48$.

Distribution: Endemic.

\section{Plantago gunnii Hook.f.}

Description: Curtis (1967).

Habitat: Found only in bolster moor communities on the dolerite mountains of Tasmania.

Chromosome number: $2 \mathrm{n}=36$.

Distribution: Endemic.

\section{Plantago triantha Sprengel}

Description: Curtis (1967).

Habitat: A halophyte which colonises salt-spray zones of coastal rocks in northwest, west and southeast Tasmania.

Chromosome number: $2 \mathrm{n}=12$.

Distribution: Tasmania, New Zealand.

\section{Plantago muelleri Pilger}

Description: Briggs et al. (1977).

Habitat: See remarks below.

Chromosome number: $2 \mathrm{n}=$ ? Briggs (1973) reports $2 n=36$ for NSW plants. W.D. Jackson (pers. comm.) found $2 n=12$ in plants from the ACT, but his voucher specimens are $P$. glacialis.

Distribution: NSW, not confirmed for Tasmania.

Comments: I have not seen any of Curtis' material, but her description of $P$. muelleri (Curtis 1967) differs from typical $P$. muelleri in having scapes which are elongated at anthesis. It appears to be nearer to $P$. glacialis, a species formerly included in $P$. muelleri. However, both $P$. mueller $i$ and $P$. glacialis have a tuft of golden-brown hairs in the leaf axils, a character not mentioned by Curtis. P. muelleri sensu Curtis (1967) has bracts "about as long as the calyces, elliptical, mucronulate" whereas $P$. glacialis has bracts "triangular acute $1.5-3 \mathrm{~mm}$ long" and sepals "2-2.2mm long" (Briggs et al. 1977).

The description given by Curtis is most similar to depauperate specimens of $P$. daltonii. In the field, such plants are characterised by short scapes with flowers frequently reduced to $1(-4)$ to a head, but on transplantation they assume the typical $P$. daltonii form. These plants occur in alpine areas, frequently forming mats in habitats similar to those described by Curtis for $P$. muelleri. The situation is further confused by the occurrence of forms of $P$. paradoxa which accord closely with the vegetative descriptions of $P$. muelleri sensu Curtis, but which, in respect of floral characters and on transplantation, are "good" $P$. paradoxa. Clearly the status of $P$. muelleri sensu Curtis requires clarification. For clarity, $P$. muelleri sensu Briggs et al. (1977) has been included, but its presence in Tasmania remains unconfirmed. 


\section{Plantago glacialis Briggs, Carolin et Pulley}

Description: Briggs et al. (1977)

Habitat: Forms mats in apine areas, found at Mt Rufus and Mt Geryon in Tasmania.

Chromosome number: $2 \mathrm{n}=$ ? Briggs (1973) and Jackson (see 8 . above) report $2 n=12$ for mainland material.

Distribution: Tasmania, NSW, Victoria.

Comments: The Tasmanian specimens bear strong resemblance to some forms of $P$. paradoxa, which exhibits considerable phenotypic plasticity (Brown 1983). The status of the Tasmanian populations could be clarified by chromosome counts since $P$. paradoxa has $2 \mathrm{n}=48$ and $P$. glacialis has $2 \mathrm{n}=12$.

\section{Section Coronopus}

10. Plantago coronopus L. Ssp. coronopus

Description: Curtis (1967), Briggs et al.(1977), Briggs B. G. (ined).

Habitat: A widespread weed, naturalised in dunes, swales and saltmarshes.

Chromosome number: $2 \mathrm{n}=10$.

Distribution: Introduced, native in Europe and Asia.

\section{Plantago coronopus L. ssp. comutata (Guss.) Pilger}

Description: B. G. Briggs (pers. comm.), Pilger (1937).

Habitat: Recorded from the Jordan River and the South Esk River at Perth.

Chromosome number: $2 \mathrm{n}=$ ?

Distribution: Introduced, native of southern and eastern Mediterranean region.

\section{Section Virginica}

\section{Plantago australis Lam.}

Description: Rahn (1974).
Habitat: Naturalised in pastures, dune swales and ruderal areas of lowland western Tasmania.

Chromosome number: $2 \mathrm{n}=$ ? Rahn (1974) reported $2 \mathrm{n}=24,48$ for South American plants.

Distribution: Introduced from South America.

Comments: This species contains a number of subspecies (Rahn 1974). A Tasmanian specimen at Kew has been identified by Rahn as $P$. australis spp. cumingiana (B. G. Briggs, pers. comm.), but specimens at MELB (B. G. Briggs, pers. comm.) and those at HO key to $P$. australis spp. sodiorana.

\section{Section Mesembrynia}

\section{Plantago varia $\mathrm{R}$. Br.}

Description: Briggs et al. (1977).

Habitat: Widespread on the dry plains and rocky slopes of the eastern half of the state in grassland, savanna woodland and dry sclerophyll communities.

Chromosome number: $2 \mathrm{n}=24$ (Brown and Jackson 1982). Curtis (1967) reported $2 \mathrm{n}=12,24$. All of the Australian mainland plants studied by Briggs (1973) were $2 n=24$.

Distribution: Tasmania, temperate Australia.

\section{Plantago debilis $\mathrm{R} \cdot \mathrm{Br}$.}

Description: Curtis (1967), Briggs et al. (1977).

Habitat: Localised in dry sclerophyll forests in northeastern Tasmania.

Chromosome number: $2 \mathrm{n}=12$.

Distribution: Tasmania, Victoria, NSW, Queensland, South Australia, and southern parts of the Northern Territory.

\section{Plantago bellidioides Decne.}

Description: Curtis (1967).

Habitat: Common in dune herbfields and grasslands of northeastern and northwestern or western Tasmania. 
Chromosome number: $2 n=12$.

Distribution: Endemic.

\section{Plantago hispida R. Br.}

Description: Briggs et al. (1977).

Habitat: Widespread in grasslands and Allocasuarina stricta low open forests along the coastal cliffs and rocky headlands of north, east and southeast Tasmania.

Chromosome number: $2 \mathrm{n}=12$.

Distribution: Tasmania, temperate Australia.

Comments: Since the work by Curtis (1967), this species has been returned to specific rank by Briggs $e t$ al. (1973). In Tasmania, the species is very much habitat limited, and shows consistent morphological variation from its nearest ally, $P$. varia. The differentiation is maintained when plants of the two species are grown in a common environment.

\section{Plantago antarctica Decne.}

Description: Curtis (1967), Briggs et al. (1977).

\section{Habitat}

Local in sub-alpine and alpine grasslands of the Central: Plateau and North-East.

Chromosome number: $2 \mathrm{n}=12$.

Distribution: Tasmania, Victoria, NSW.

Comments: See comments under $P$. glabrata.

\section{Plantago gaudichaudii Decne.}

Description: Briggs et al. (1977).

Habitat: Grassy dry sclerophyll.

Chromosome number: $2 n=24$. Briggs (1973) reports $2 \mathrm{n}=12,24,36$ for mainland plants.

Distribution: Recorded from Rosny Esplanade (MJB) and by L. Rodway in 1928 from Blackmans Bay in Tasmania, temperate Australia.

Comments: This species is not included by Curtis (1967).

\section{Plantago glabrata Hook.f.}

Description: Curtis (1967).

Habitat: Sub-alpine grasslands and shrublands of the Central Plateau and Eastern Tiers.

Chromosome number: $n=12,2 n=24$; found in both the narrow- and broad-leaf variants of this species.

Distribution: Endemic.

Comments: This species typically shows the development of a trilocular ovary and should be referred to section Mesembrynia pending a review of Pilger's classification.

Some forms of $P$. glabrata may be mistaken for $P$. antarctica if the key characters given by Curtis (1967) are used to identify them, viz. "leaves with 3-7 almost equal parallel veins" ( $P$. antarctica) or "leaves with midrib distinct but lateral veins not, or scarcely conspicuous" ( $P$. glabrata). Consequently, some common variants of $P$. glabrata which have broad leaves would key to $P$. antarctica on the basis of the above characteristics. However, the two species have different chromosome numbers $(P$. antarctica, $2 \mathrm{n}=12$; $P$. glabrata, $2 \mathrm{n}=24$ ) and can be more satisfactorily distinguished as follows. $P$. glabrata has leaves with an elongate, narrow petiole and floral bracts which have fimbriate-ciliate margins and are as long or longer than the calyces. $P$. antarctica has leaves which narrow gradually to a short, broad petiole and floral bracts which have entire margins and are only $1 / 2$ to $3 / 4$ as long as the calyces. These characteristics can readily be used to distinguish plants in the field, because the bracts and sepals are persistent in both species and old scapes remain on the plants for most of the year.

$P$. glabrata exhibits both within population and clinal variation in leaf-form across the Central Plateau, the cline being correlated with precipitation rather than temperature (Brown 1979). The westernmost narrow and broad leaf-forms exhibit close morphological resemblances to the upland mainland Australian species $P$. alpestris and $P$. euryphylla respectively (Briggs et al. 1973, 1977, Costin et al. 1979.) However, these two species differ from $P$. glabrata in the following respects: both mainland species lack the development of the trilocular ovary typical of $P$. glabrata, neither species produces the long, persistent tap-root of $P$. glabrata and the diploid chromosome number of both species is $2 \mathrm{n}=12$, whereas $P$. glabrata has $2 \mathrm{n}=24$. Further study is required to determine whether the western morphs of $P$. glabrata warrant specific recognition. 


\section{Section Arnoglosum}

\section{Plantago lanceolata L.}

Description: Curtis (1967), Briggs et al. (1977).

Habitat: Widespread in lawns, pastures, roadsides and rough grazing areas. In some areas, e.g. Mt Nelson, the species is invading woodlands occupied by $P$. varia.

Chromosome number: $2 \mathrm{n}=12$.

Distribution: Introduced, native in Europe and Asia.

\section{DISCUSSION}

\section{Cytology}

Cytological studies (e.g. McCullagh 1934) have been of little assistance in demonstrating affinities at the family level, although they have been valuable in suggesting probable lines of diversification within the genus Plantago.

There appear to be at least three series of multiple chromosome numbers in the genus. The probable primitive base number is $x=6$, giving rise to the polyploid series $12,24,36,48$ and 72 . The other two series appear to derive from aneuploids, with bases $\mathrm{x}=5(2 \mathrm{n}=10,20,30)$ and $\mathrm{x}=4(2 \mathrm{n}=8,16)$ (McCullagh 1934, Maude 1939, Rahn 1957, Bassett 1967, Groves \& Hair 1971, Briggs 1973, Brown \& Jackson 1982).

Polyploid races are known to occur within some species of the genus, but the occurrence of polyploidy does not appear to be well correlated with morphological variation at either the intra or interspecific level. For example, Rahn (1974) found that polyploid races of $P$. australis $(2 \mathrm{n}=24,48)$ did not exhibit obvious morphological differences, and a similar result was found by Briggs (1973) for $P$. gaudichaudii $(2 \mathrm{n}=12$, 24, 36). Bassett \& Crompton (1968) found no overall correlation between chromosome number and pollen size of North American taxa. Bocher et al. $(1953,1955)$, in an investigation of the cytogeographic variation of $P$. coronopus, found diploid and hexaploid races within the species, but found that the morphological differences between the ploidy levels were less than those observed among the races of the diploid type. McCullagh (1934) found some agreements between chromosome number and Decaisne's division of the genus (1852).

The consensus of these reports has been put succinctly by Briggs (1973):
"Polyploidy is fairly common, but the primary diversification within the genus has apparently not been accompanied by change of either base number or level of ploidy."

The chromosome numbers of the Tasmanian representatives of the genus Plantago are given in table 1 . Polyploids occur in both sections of the genus native to Tasmania. In section Oliganthos, reported chromosome numbers are $2 \mathrm{n}=12(P$. tasmanica, $P$. daltonii, $P$. triantha), $2 \mathrm{n}=36(P$. gunnii $)$ and $2 \mathrm{n}=48$ ( $P$. paradoxa). In section $M e s e m b r y n i a$, the species are either $2 \mathrm{n}=12(P$. debilis, $P$. bellidioides, $P$. hispida, $P$. antarctica) or $2 \mathrm{n}=24(P$. varia, $P$. glabrata). Curtis (1967) reports diploid $(2 n=12)$ and tetraploid $(2 n=24)$ populations of $P$. varia in Tasmania, but Briggs (1973) found that all of the Australian mainland plants studied were tetraploid. Brown and Jackson (1982) found only $2 n=24$ in $P$. varia from Tasmania.

\section{Breeding Systems}

The genus has hermaphrodite flowers which are protogynous, largely wind-pollinated and outbreeding, although exceptions do occur. Thus $P$. media produces flowers which are scented, have coloured stamens and are at least partly insect-pollinated. Members of the section Novorbis produce cleistogamous flowers and these species were held by Pilger (1937) to be apomictic, although no evidence for this was found by Rahn (1974). Pilger reported dioecy in $P$. tubulosa Decne. and $P$. rigida Kunth., and gynogioecy in $P$. lanceolata.

The occurrence of protogyny provides a measure of facultative outbreeding, at least in the early part of the season, but unless self-incompatability mechanisms are present, selfing can occur by fertilisation of younger inflorescences of the same plant. In a survey of the breeding systems of eleven species of Plantago, Ross (1970) found a diversity from facultative inbreeding to obligate outbreeding. Of particular interest was the occurrence of both self-incompatibility mechanisms and gynodioecy in populations of three species. Even more remarkably, it was found that, whilst both selfincompatibility and gynodioecy occurred in populations of $P$. maritima located in Europe, the American populations of the same species were self-compatible and not gynodioecious.

No detailed studies of the breeding systems of the native Tasmanian species have been reported in the literature, but my own field observations suggest that, with the possible exceptions of $P$. paradoxa and $P$. gunnii, all of the species are perennial, protogynous, outbreeding and wind-pollinated. $P$. paradoxa and $P$. gunnii are perennial and protogynous, but produce 
flowers on scapes which are (sub-)sessile at anthesis, so self-pollination may be more common in these species. However, both species probably are capable of outbreeding to some degree. $P$. paradoxa occupies wet sites where cross-pollination could occur via waterborne pollen. Plants of $P$. gunnii occur within "cushion plants", where they are elevated above the ground surface. Their stamens have versatile anthers on very long filaments so that some wind-pollination is likely.

All of the known native Tasmanian species have been grown in isolation at some stage and all appear to be fully self-compatible. No evidence for gynodioecy was found in any of the species. Populations of some members of section Mesembrynia ( $P$. glabrata, $P$. varia, $P$. hispida, $P$. debilis, $P$. bellidioides) appear to show polymorphism in flowering time, but this does not occur in species from section Oliganthos ( $P$. paradoxa, $P$. triantha, $P$. daltonii) or in the introduced species (P. lanceolata, P. major and P. australis) (Brown 1979).

In the field, flowers are produced during springsummer (September-January) in all species, and seedset occurs from late spring to the end of summer (November-February). It is probable that all species produce only one generation per year, although it may be possible for an early flowering phenotype to produce plants which set seed prior to the onset of winter. This aspect of the life cycle of the species requires further study.

\section{Phenotypic Modification}

Many of the species exhibit extensive phenotypic plasticity (Marsden-Jones \& Turrill 1930-45, Salisbury 1952, Gregor \& Watson 1961, Brown 1979, 1981, 1983 ) and some of the habitat-induced modifications have been shown to correspond closely to previously described infra-specific taxa. Thus Marsden-Jones \& Turrill (1939-45) were able to demonstrate the correspondence between edaphically induced modifications of $P$. major and varieties described by Pilger (1937). Similarly, Salisbury (1952) showed that the form adopted by plants described as $P$. coronopus var. pygmaea was habitat-induced as, on transplanting, the plants assumed the "typical" form of $P$. coronopus. However, Bocher et al. (1955) also demonstrated that in some cases this dwarf form is genetically fixed. Brown $(1979,1983)$ demonstrated a similar propensity for phenotypic plasticity and stability in $P$. paradoxa.

Ecotypic and ecoclinal variation in a variety of characters has been demonstrated for a number of species. Much of this variation is genetically based. Gregor (1930) found quantitative differences in the spike:scape length ratio in $P$. maritima from different habitats were under genetic control. Groot \& Boschhuizen (1970) have found heritable differences of leaf-form along populations of $P$. major and Bocher et al. (1955) found that geographically distinct races of $P$. coronopus are maintained genetically.

From the examples given here it can be seen that, within a single species of the genus, there are characters capable of exhibiting morphological differences which are habitat-correlated, and which may simultaneously be genetic in origin and yet exhibit plastic modification.

The studies by Brown $(1979,1981,1983)$ demonstrated a widespread capacity for phenotypic and more directly genetically-based variability in the Tasmanian species of Plantago. For example, there is evidence of ecotypic variation in $P$. tasmanica and ecoclinal variation in $P$. glabrata, the variation being made manifest in a range of vegetative, floral and ecophysiological characteristics. Of particular significance is the ability exhibited by many species to produce canalised phenotypic responses, which frequently may mask underlying genetic variation. Such variability or apparent lack thereof makes the task of the field botanist and the taxonomist particularly difficult!

\section{ACKNOWLEDGEMENTS}

I wish to thank the following people for their assistance with various aspects of the work: B. Briggs, R. Crowden, W. Curtis, Y. Farrell, W. Jackson, J. Jarman, G. Kantvilas and A. Orchard.

\section{REFERENCES}

BARNEOUD, F.M., 1845: MONOGRAPH GENERA DE LA FAMILLE DES PLANTAGINEES.

BASSETT, H.I.S., 1967: Taxonomy of Plantago L. in North America, sections Holopsyllium Pilger, Palaeopsyllium Pilger and Lamprosantha Dcne. Can.J. Bot. 45: 565.

Bassett, H.I.S. \& Crompton, C.W., 1968: Pollen morphology and chromosome numbers of the family Plantaginaceae in North America. Can. J. Bot. 46: 349-161.

BENSON. L., 1957: PLANT CLASSIFICATION. D.C. Heath Co., London.

Bentham, G. \& HoOKeR, J.D., 1862-83: GENERA PLANTARUM. London.

BEsSEY, C.E., 1897: Phylogeny and taxonomy of the Angiosperms. Bot. Gaz. 24: 145-178.

BOCHER, T.W., LARSON, K. \& RAHN, K., 1953: Experimental and cytological studies on plant species I. Hereditas 39: 289-302.

BOCHER, T.W., LARSON, K. \& RAHN, K., 1955: Experimental and cytological studies on plant species III. Hereditas 41: 423-453. 
Briggs, B.G., 1973: Chromosomal studies on Plantago in Australia Cont. NSW Nat. Herb. 4: 399-405.

Briggs, B.G., 1977: Research on Plantago. Aust. Plants 9: 84. Briggs, B.G., Carolin, R.C. \& Pulley, J.M., 1973: New species and leptotypification in Australian Plantago. Cont. NSW Nat. Herb. 4: 395-398.

Briggs, B.G., Carolin, R.C. \& Pulley, J.M., 1977: Plantaginaceae. In Tindale, M.D. (Ed.): FLORA OF NEW SOUTH WALES. No. 181. National Herbarium of New South Wales.

Brown, M.J., 1979: Studies of variation in some Tasmanian species of Plantago L. Unpubl. PhD thesis, University of Tasmania.

Brown, M.J., 1981: An experimental taxonomic study of Plantago tasmanica Hook. J. and $P$. daltonii Dcne. Aust. J. Bot. 29: 441-452.

Brown, M.J., 1983: Phenotypic plasticity and stability of leaf form in Plantago paradoxa Hook. f, in mosaic environments. Aust. J. Bot. 31: 323-330.

Brown, M.J. \& Jackson, W.D., 1982: Chromosome numbers in Tasmanian Plantago species. Taxon 31:367-368.

Costin, A.B., Gray, M., TotTerdell, C.J. \& Wimbush, D.J., 1979: KOSCIUSKO ALPINE FLORA. CSIRO/ Collins, Australia.

Cronquist, A., 1968: THE EVOLUTION AND CLASSIFICATION OF FLOWERING PLANTS. T. Nelson \& Sons, London.

Curtis, W.M., 1967: THE STUDENT'S FLORA OF TASMANIA, PART 3. Govt Printer, Hobart.

DAHLGREN, R, 1975: A system of classification of the Angiosperms to be used to demonstrate the distribution of characters. Bot. Notiser 128: 119-147.

DeCaisne, J., 1852: Plantaginaceae. In D.C. Prod. XIII: 693737.

DE WIT, H.C.D., 1965: PLANTS OF THE WORLD. THE HIGHER PLANTS. II. Thames and Hudson, London.

Engler, A. \& PRANTl, K., 1897. DIE NATURLICHE PFLANZENFAMILIEN IV(3b): 363-373.

GoOD, R., 1965: THE GEOGRAPHY OF FLOWERING PLANTS. Longmans, New York.

GREGOR, J.W., 1930: Experiments on the genetics of wild populations I Plantago maritima. J. Genet. 22: 15.

Gregor, J.W. \& Watson, P.J., 1961: Ecotypic differentiation: observations and reflections. Evolution 15 : 166-173.
Groot, J. \& Boschuuizen, R., 1970: A preliminary investigation into the genecology of Plantago major. J. Expl. Bot. 21: 835.

Groves, B.E. \& HAIR, T.B., 1971: Contributions to a chromosome atlas of the New Zealand flora. 15 , Miscellaneous families. NZ J. Bot. IV: 569.

HutchINSON, J., 1959: FAMILIES OF FLOWERING PLANTS. DICOTYLEDONS. Clarendon Press, New York.

Hutchinson, J., 1969: EVOLUTION AND PHYLOGENY OF FLOWERING PLANTS. Academic Press, London.

LAWRENCE, G.H.M., 1951: TAXONOMY OF VASCULAR PLANTS. Macmillan and Co., New York.

McCullagh, D., 1934: Chromosomes and chromosome morphology in Plantaginaceae I. Genetica 16: 1-44.

Marsden-Jones, E.M. \& Turrill, W.B., 1930-45: Report on the transplant experiments of the British Ecological Society at Poterne, Wilts. J. Ecol. 18: 352 (1930); 21: 268 (1933); 23: 443 (1935); 25: 189 (1937); 26: 359 (1938); $33: 57$ (1945).

Maude, P.F., 1939: The Merton Catalogue. New Phytol. 38: $1-31$.

PILGer, R., 1937: Plantaginaceae. In Das Pflanzenreich IV: 269, H. 102.

RAHN, K., 1957: Chromosome numbers in Plantago. Bot. Tidsskr. 53: 369-378.

RaHn, K., 1974: Plantago section Virginica. Dansk. Bot. Arkiv. 30: $1-180$.

Ross, D., 1970: Breeding systems in Plantago. Heredity 25 : $129-133$.

SalisbUry, E., 1952: DOWNS AND DUNES. G. Bell and Sons, London.

TAKHATAJAN, A., 1969: FLOWERING PLANTS: ORIGIN AND DISPERSAL. Oliver and Boyd, London.

Thorne, R.F., 1968: Synopsis of a putatively phylogenetic classification of the flowering plants. Aliso 6: 57 66.

WILLIS, J.C., 1973: A DICTIONARY OF THE FLOWERING PLANTS AND FERNS. 8th edn, Cambridge University Press, UK.

WILlis, J.H., 1972: A HANDBOOK TO PLANTS IN VICTORIA. II. DICOTYLEDONS. Melbourne University Press, Melbourne.

(accepted 10 August 1990)

M.J. Brown

Forestry Commission, GPO Box 207B, Hobart, Tasmania, Australia 7001; formerly Botany Department, University of Tasmania 


\section{TABLE 1}

Chromosome Numbers of Tasmanian Plantago Species

\begin{tabular}{|c|c|c|c|}
\hline \multicolumn{2}{|c|}{$\begin{array}{l}\text { Chromosome } \\
\text { number }\end{array}$} & \multirow[t]{2}{*}{ Species } & \multirow[t]{2}{*}{ Authority* } \\
\hline$n$ & $2 n$ & & \\
\hline- & 10 & $\begin{array}{l}\text { P. coronopus } \\
\text { P. major } \\
\text { P. lanceolata } \\
\text { P. tasmanica var. tasmanica } \\
P . \text { daltonii } \\
P . \text { triantha }\end{array}$ & $\begin{array}{l}2,4 \dagger \\
2,4 \dagger \\
2,4 \dagger \\
4 \dagger \\
4 \dagger \\
4 \dagger\end{array}$ \\
\hline - & 12 & $\begin{array}{l}P . \text { glacialis } \\
P . \text { debilis } \\
P . \text { bellidioides } \\
P . \text { hispida } \\
\text { P. antarctica }\end{array}$ & $\begin{array}{l}2,4 \\
2,4 \dagger \\
5 \dagger \\
2,4 \dagger \\
2,4 \dagger\end{array}$ \\
\hline - & 24 & $\begin{array}{l}\text { P. varia } \\
\text { P. glabrata }\end{array}$ & $\begin{array}{l}2,4 \dagger \\
4 \dagger\end{array}$ \\
\hline- & 36 & $\begin{array}{l}P . \text { gunnii } \\
P . \text { muelleri }\end{array}$ & $\begin{array}{l}4 \dagger \\
2\end{array}$ \\
\hline- & 48 & $P$. paradoxa & $4 \dagger$ \\
\hline- & 12,24 & P. varia & $1 \dagger$ \\
\hline- & $12,24,36$ & P. gaudichaudii & 2 \\
\hline- & 24,48 & $P$. australis & 3 \\
\hline 12 & 24 & $\begin{array}{l}P . \text { glabrata } \\
\text { (narrow leaf form) }\end{array}$ & $4 \dagger$ \\
\hline 12 & 24 & $\begin{array}{l}\text { P. glabrata } \\
\text { (broad leaf form) }\end{array}$ & $4 \dagger$ \\
\hline
\end{tabular}

* Authority: 1 - Curtis (1967); 2 - Briggs (1973); 3 - Rahn (1974); 4 - Brown \& Jackson (1982).

$\dagger$ Determinations made on Tasmanian material. 